\section{A comunicação pelo meio (teoria complexa da comunicação)}

\section{RESUMO}

0 artigo trata da complexa relação entre os meios de comunicação e a sociedade num mundo cada dia mais mediado tecnologicamente. Morin questiona o papel da mídia e, principalmente chama atenção para a questão referente ao potencial do receptor. Para 0 autor 0 desenvolvimento tecnológico da comunicação não substitui a compreensão, sendo esse um problema filosófico da humanidade.

\section{ABSTRACT}

This paper discusses the complex relationship between the means of communication and society in a world increas-ingly dependent on technology. The author questions the role of the media and the potential of the receiver, considering that the technological development of the communications is not a substitute for comprehension.

\section{PALAVRAS-CHAVE (KEY WORDS)}

- Mídia (Media)

- Imaginário (Imaginary)

- Complexidade (Complexity)

\section{Edgar Morin}

CNRS/França
De alguma maneIRA, eu nunca me interessei pela comunicação em si mesma, embora tenha tratado de temas adjacentes em livros como O Cinema e o homem imaginário, Cultura de massa no século XX e As Estrelas, isso pela simples razão que me parecia fundamental refletir sobre a cultura de massa, evidentemente uma cultura que só pôde desenvolver-se graças aos mídia. Essencial não era constatar que a mídia permitia uma explosão da comunicação, mas que trazia consigo as condições de criação de uma nova arte e de uma nova indústria, como o cinema e a televisão.

Em meu livro As estrelas, por exemplo, abordei a mitologia das estrelas de cinema. A existência desses novos mitos era a conseqüência de uma cultura de massa gerada pelos novos meios de comunicação. Esse cruzamento é que sempre me interessou e continua me parecendo muito importante do ponto de vista de pesquisa e de compreensão da complexidade comunicacional e cultural contemporâneas. O tema da comunicação permanece decisivo, mas só faz plenamente sentido quando é tomado em conexão com outros fenômenos socioculturais e políticos: que significa comunicar? Como se comunicar?

Quando falo de mundialização ou de globalização, fenômenos que se tornam centrais nos últimos dez anos do século $\mathrm{XX}$, é evidente que percebo o papel relevante exercido pelo desenvolvimento extraordinário dos meios de comunicação e das novas tecnologias (informática, internet, fax, e-mails, telefones celulares, tecnologias digitais...) na consolidação e difusão desse estado das coisas. Mesmo assim, não reduzo a globalização ao 
fator comunicacional, pois a comunicação não existe sozinha e está sempre em relação com outros problemas. Para usar a linguagem de hoje, a pesquisa em comunicação exige sempre o exame da interface da comunicação com outras áreas do conhecimento. Por isso, nunca me tornei um comunicólogo.

Hoje, considero prioridade criticar o mito da comunicação. Existem afirmações, verdadeiros slogans, que não contam do real e geram novos reducionismos. Diz-se que estamos na "sociedade da informação", na "sociedade da comunicação" ou na "sociedade do conhecimento". Refuto. Estamos em sociedades de informação, de comunicação e de conhecimento. Claro que estamos em sociedades de informações, até do ponto de vista físico, da teoria da informação, basta pensarmos nas tecnologias digitais (DVD, televisão digital, etc.), que são aplicações da teoria da informação. Mas a informação, mesmo no sentido jornalístico da palavra, não é conhecimento, pois o conhecimento é o resultado da organização da informação.

Ora, na atualidade, temos excesso de informação e insuficiência de organização, logo carência de conhecimento. Eis a razão para evitar o discurso publicitário que produz uma euforia que excede os ganhos conquistados e mascara os problemas surgidos. Ao discurso eufórico que diz "tudo comunica" oponho outra afirmação: quanto mais desenvolvidos são os meios de comunicação, menos há compreensão entre as pessoas. A compreensão não está ligada à materialidade da comunicação, mas ao social, ao político, ao existencial, a outras coisas.

Tudo consiste em fazer a diferença entre comunicação, informação, conhecimento e compreensão. Por isso, sempre cito Eliot: "Qual é o conhecimento que perdemos na informação? Qual é a sabedoria que perdemos no conhecimento?" Ou seja, a sabedoria é a capacidade de integrar, incorporar conhecimentos à vida cotidiana. É fácil constatar que estamos vivenciando uma degradação do conhecimento na/pela informação, acarretando uma degradação da arte de viver no/pelo conhecimento. Precisamos separar todas essas noções para melhor compreendê-las e praticálas. A compreensão humana é um tipo de conhecimento que necessita de uma relação subjetiva com o Outro, de simpatia, o que é favorecido, talvez, pela projeção, pela identificação, como ocorre quando vamos ao cinema ou lemos romances e simpatizamos com os personagens. A compreensão, mais do que a comunicação, ou em conseqüência desta, é o grande problema atual da humanidade.

Paradoxalmente, pode-se dizer que a comunicação não pode substituir a compreensão. Dito de outra maneira, para a compreensão não basta a comunicação. Bem entendido, a compreensão pode ser afetada ou ajudada pela comunicação, seja tecnicamente (telefone, e-mail, fax), seja pelo domínio do código (língua). Essas condições de base. Mas é preciso que a compreensão exista, aconteça, pois a comunicação por si mesma não pode criála. A compreensão não é, essencialmente, um problema de meios, mas de fins. É um problema que questiona o aspecto subjetivo profundo da pessoa. Nesse sentido, é um problema filosófico.

A comunicação depende de meio; os fins podem estimular a decodificação das mensagens. Já a compreensão pode estar aquém ou além disso tudo. Pode vir, por exemplo, da compaixão, de uma simpatia, de um amor. Na compreensão há sempre um componente afetivo. Fala-se muito em comunicação e na hegemonia da mídia em nossa época. Trata-se de uma concepção que não compreende bem o fenômeno e isola o papel dos meios de comunicação, dando a estes uma autonomia exagerada. É um clichê que atravessou o século XX e, apesar dos esforços de pesquisa, não foi dissipado.

Nos Estados Unidos, nos anos trinta do século passado, havia uma grande 
inquietação: imaginava-se que o cinema estimulava a violência e a delinqüência juvenil. Depois, passou-se a fazer a mesma acusação contra a televisão. Enfim, uma concepção totalmente vulgar do marxismo, embora sustentada por autores importantes como Marcuse, defendeu que a mídia favorecia a alienação de trabalhadores, impedindo-os de tomar consciência dos seus próprios problemas. No Brasil mesmo, muitos intelectuais ainda pensam que o futebol é o "ópio do povo" e aliena os torcedores. As coisas são simplesmente mais complexas. Pode-se amar o futebol e ter consciência da realidade social. Quando falta essa consciência o responsável não é o futebol, mas certamente a situação política, social e educacional do país. Ver telenovelas não impede de ter consciência política e de contestar as injustiças sociais.

As teorias da alienação pela comunicação e pelo entretenimento são frágeis e têm enfrentado revisões e refutações constantes. Pesquisas já mostraram que a mídia pode influenciar na vida das pessoas, mas que ela não desempenha um papel determinante no essencial. As causas profundas da violência juvenil não estão na mídia, mas na desintegração familiar, no tipo de vida levada nos bairros problemáticos, na miséria e na falta de perspectivas, sem contar a formação de novos guetos marcados pelo preconceitos e por todos os tipos de exclusão social. Se existem bandidos, gângsteres, não é porque os indivíduos foram demais ao cinema ou viram televisão em excesso.

Precisamos falar claramente de comunicação, evitar as teorias obscuras e o rebuscamento inútil. As sociedades sempre tiveram seus subterrâneos, submundos, espaços marginais, violência, criminalidade, etc. A mídia não inventou nada disso, embora torne esses fenômenos mais visíveis. É disso que as teorias da comunicação precisam tratar. Shakespeare já mostrava o lado escuro da humanidade e não podemos acusá-lo de estimular a violência. A única diferença, no caso, é que os criminosos de Shakespeare eram reis, enquanto os nossos são traficantes de drogas ou serial killers, embora também os tenhamos entre os chefes de Estado. A mídia não inventou o crime, que faz parte da história da humanidade. Basta dar uma olhada nas tragédias gregas, em "Medéia", na história de Édipo, homem que mata o pai e faz sexo com a mãe. Será que isso fez aumentar o número de incestos? Não.

Antes do cinema, o que se contava às crianças? Os contos de Perrault: a história de um ogro que come crianças. É horrível. Chapeuzinho Vermelho: história de uma menina que vai à casa da avó e, no lugar da velhinha, encontra um lobo; a criança é devorada. Será que essas narrativas terríveis não cumprem uma tarefa pedagógica: ensinar às crianças que existem coisas horríveis no mundo? Nem por isso as crianças, tornadas adultas, começaram a devorar os outros. A mídia não inventou o mal.

A questão é outra: como enfrentar os problemas de civilização? À noite, na França, no Brasil imagino que aconteça o mesmo, são exibidos programas de entretenimento (filmes, westerns, programas de auditório, etc.). A reação politicamente correta consiste em afirmar que isso serve para imbecilizar as pessoas. Os homens e mulheres que trabalham durante o dia, situação da maioria, voltam cansados e necessitam de relaxamento, de distração e de divertimento. Se a civilização, a cultura, fosse outra, mais centrada no lazer, na qual os seres humanos não estivessem diuturnamente ocupados com a produção, ou ocupados pela produção, pode ser que cada um buscasse mais nos meios de comunicação outro tipo de programação.

O problema é mesmo de civilização. Além disso, a existência comporta uma parte lúdica, aberta aos jogos e às brincadeiras. A televisão atende parte dessa necessidade lúdica. As crianças, agora, gostam de videogames, mas antes 
elas tinham outros jogos. Os adultos também gostam e necessitam de evasão, de jogo, de ficção e de distração pura e simples. Precisamos, portanto, ter uma visão multidimensional da realidade humana. Na vida, no cotidiano, a mídia desempenha um papel, porém não se trata do papel central nem mesmo de um só papel. A sua influência depende de contexto, de filtros, de situações históricas, de percursos individuais e de uma série de outros fatores.

As primeiras grandes pesquisas de campo sobre os meios de comunicação, nos Estados Unidos, feitas por Lazarsfeld e outros, já diziam que o problema não era saber o que a mídia faz de nós, mas o que nós fazemos da mídia. A primeira hipótese (o que a mídia faz de nós ou conosco) toma o destinatário de uma mensagem como um estúpido, colocandoo numa situação de passividade absoluta. Todas essas sociologias da manipulação tomam o telespectador, o ouvinte, o leitor, o destinatário, enfim, como imbecis culturais, seres incapazes de compreensão e de leitura crítica. Trata-se de reducionismo e de preconceito sob a máscara de crítica radical da alienação pela mídia.

Qualquer pessoa, mesmo a mais retrógrada ou desinformada, quando vai ao cinema, é capaz de saber que se trata de cinema, ou seja, sabe separar a realidade da ficção, o possível do vivido e o espetáculo do cotidiano. Mesmo se a pessoa chora, ri, participa, ela continua ciente de que essa identificação se dá com o imaginário. Qualquer um que vá ao cinema tem uma consciência complexa, forjada por experiências de vida e aptidões intelectuais. A educação formal é apenas uma das possibilidades de educação dos sentidos. Existe uma sabedoria nãoacadêmica. O intelectual que reduz 0 espectador de massa à condição de imbecil não possui essa consciência complexa, embora imagine o contrário. Existe muita discussão sobre o papel da mídia e pouca clareza quanto ao seu real poder no cotidiano das pessoas.

É inegável que a mídia difunde muita coisa medíocre. Em A Cultura de massa no século $X X$, mostrei que Hollywood empregava meios industriais para fazer filmes, operando com base na divisão do trabalho, na especialização das funções, num certo números de regras incontornáveis (final feliz, história de amor, protagonistas belos, encontros e desencontros, etc.) e na determinação de ganhar dinheiro. Apesar disso, excelentes filmes foram realizados e, algumas vezes, obras-primas. O cinema produz a façanha, por vezes, de unir indústria e arte. Por quê? A razão é simples e dialógica: não basta a produção para fazer um filme; é necessário criação, invenção, originalidade, inovação. Os cineastas, chamados para atingir tais objetivos, ou decididos a encontrar espaço nesse meio, podem ter muito talento ou ser mesmo geniais. Resultado: joga-se com a situação, com as restrições, com as possibilidades e, com freqüência, consegue-se o inimaginável.

John Ford, por exemplo, soube fazer as limitações da indústria cinematográfica, compor com elas, e conceber obras de arte. Ele tomou as marcas do gênero, do Western, que são fatores de limitação ao gênero, e transformou-as em raízes, tirando delas seiva para a sua criação. Certamente que a produção pode sufocar a criação. Toda história de Orson Welles é a de uma luta entre a criação e a produção, entre o artista e a indústria, entre o gênio e os elementos de limitação da sua época: fatores técnicos, econômicos, estéticos, expectativas dos produtores, gostos dominantes, etc. Apesar disso tudo, Welles concebeu, ao menos, duas obras-primas. Sabemos que não conseguiu realizar alguns projetos. Foi sufocado. Mas deixou a sua inacreditável marca em nossas mentes e corações.

Artistas foram sufocados, como Erich von Stroheim, o que é incontestável. Em literatura, contudo, coisas semelhantes acontecem. Quando Marcel Proust propôs 
aos diretores da Gallimard seu livro Em Busca do tempo perdido, recebeu um não. A editora alegou que se tratava de histórias mundanas e sem interesse. Não são poucos os casos de editores que recusaram obras-primas. A existência de talentos, de gênios incompreendidos, é real e antecede o fenômeno da mídia. Rimbaud e Vang Gogh viveram, sofreram e foram incompreendidos antes da chamada era da mídia. O mesmo se pode dizer de Holderlin e de tantos outros.

Há um fenômeno curioso em relação à crítica da mídia: a televisão adora os intelectuais que a criticam. Nos últimos anos, Pierre Bourdieu, com Sobre a televisão, e Serge Halimi, com Os Novos cães de guarda, reativaram uma crítica fácil da mídia. Há algo de sensacionalista nesse tipo de ataque requentado, que retoma alguns slogans da Escola de Frankfurt, e o sensacional faz sensação na mídia. A televisão digere facilmente esse gênero de crítica, fazendo dos intelectuais que as assinam colaboradores em programas de debate, o que legitima a televisão, põe em contradição os seus críticos e banaliza o argumento.

Tais críticas são unilaterais. Não é por que certos jornalistas defendem certas idéias políticas, mesmo oficiais, que devem ser considerados novos cães de guarda. Este título, como se sabe, vem do livro de Paul Nizan, dirigido contra os filósofos idealistas, rotulados então de cães de guarda da burguesia. Retomar essa idéia, hoje, é algo delirante, fora de contexto, improcedente. Não podemos continuar a pensar que Henri Bergson foi um cão de guarda da burguesia. O pecado está no potencial excessivo dessa ordem de interpretação. Lutar contra o pensamento único é fundamental, mas não com outro pensamento único tão rudimentar quanto o primeiro.

O panfleto de Pierre Bourdieu é ex traordinariamente simplificador. Ao pensar o tema, no seu conjunto, cabe precisar certas coisas. Quem busca o pensamento complexo, a visão multidimensional dos fenômenos sociais, não pode se entusiasmar com perspectivas unilaterais e com críticas a tal ponto reducionistas e simplórias. O unilaterialismo de Bourdieu, sobre a televisão, contém, evidentemente, algumas verdades, porém o essencial não está lá e a totalidade de concepção produz mais erro e confusão do que esclarecimento.

Na França, houve um tempo em que a televisão não era privada, todos os canais eram públicos, e havia mais espaço para discussões intelectuais e argumentos. Podia-se responder a questões, sem pressa, durante mais de uma hora. Desde o momento em que surgiram os canais privados, voltados para a audiência, esses programas desapareceram, acusados de aborrecer os telespectadores. Por outro lado, os debates tornaram-se espetáculos, shows, sendo que o apresentador pode cortar a palavra aos que tentam se estender. Ora, a evolução tecnológica, com o surgimento dos canais a cabo, determinou o surgimento de novos canais, segmentados, sobre muitos assuntos temáticos: história, esporte, artes, etc. O debate ressurgiu. A televisão digital permitirá ainda mais canais e, logo, mais especificidade.

No canal franco-alemão "Arte" eu mesmo já debati com um filósofo alemão durante mais de uma hora. O programa foi ao ar entre onze horas e meia-noite. Para o público interessado isso não foi um problema. Não podemos pedir à televisão que ministre cursos noturnos de filosofia para todo mundo. Não podemos achar que a televisão só será boa se falar de Platão, Aristóteles e Spinoza no horário nobre. A vida não é feita só de Platão, Aristóteles e Spinoza. É pena que o público interessado em filosofia não seja maior. Em todo caso, a culpa disso não é da mídia. Esse é o problema, antes de tudo, da educação. Num país em que todos freqüentam a escola a tarefa de despertar o gosto pela filosofia é dos educadores. 
Mais do que a manipulação, precisamos estudar e compreender a relação da mídia com nossos imaginários. O cinema, por exemplo, corresponde ao mito de uma sociedade em ascensão, ao tempo de ascensão das classes populares, em determinada situação histórica, à condição de classes médias. Essa massa em ascensão alcança um mundo de individualismo e de vida privada, no qual o amor se torna cada vez mais importante. As estrelas embalam sonhos, difundemse fenômenos de mimetismo, filmes retratam a busca do sucesso, de êxito na vida, mostram os percalços, servem de consolo, de estímulo, de identificação. Por momentos, modas se impõem: mimetismo na maneira de falar, nos cortes de cabelo, nas roupas, em certas atitudes.

O cinema pornográfico influenciou certamente no gosto pela felação. Mas a felação já existia e era praticada com gosto antes. Para cada estímulo ou influência, existem outros estímulos ou influências, antagônicos, complementares, mais ou menos carregados de significação para cada indivíduo. A comunicação ocorre em situações concretas, acionando ruídos, culturas, bagagens diferentes e cruzando indivíduos diferentes. Ela é sempre multidimensional, complexa, feita de emissores e de receptores (cujo poder multidimensional não pode ser neutralizado por uma emissão de intencionalidade simples). O fenômeno comunicacional não se esgota na presunção de eficácia do emissor. Existe sempre um receptor dotado de inteligência na outra ponta da relação comunicacional. A mídia permanece um meio. A complexidade da comunicação continua a enfrentar o desafio da compreensão .

Nota

* Reflexão concebida dialogicamente, a partir de proposições baseadas na obra de Edgar Morin, por Juremir Machado da Silva, que também traduziu o texto. 